3 enzymes acid phosphatase, galactose-1-phosphate uridyl transferase and glucose-6-phosphate dehydrogenase found in mongoloid individuals, and also about Public Health Service research grants, and work on the diagnosis and study of retardation done by a new unit in the Institute. There is also a report of a discussion on saving life before birth and items on 'fetology', the name given to the situdy and treatment of the human foetus in utero, and on grants for the study of adult development and ageing.

\section{'Michrome' Stains and Reagents for Biology}

Building extensions to the premises of Edward Gurr, Ltd., at East Sheen, London, S.W.14, have now been completed at a cost of $£ 25,000$ with the view of stream. lining operations, more particularly in connexion with the firm's exports expansion programme. This is the second extension since Edward Gurr acquired the original premises in November 1950. The first was built in 1952 (Nature, $169,483,1952$ ), when the Mayor of Barnes laid the foundation stone of a new laboratory block. The ceremony was performed in the presence of officials of the Board of Trade (Export Promotion Department), Central Office of Information, the British Broadcasting Corporation and the Press. The Company was founded shortly after the Second World War by Edward Gurr, an organic chemist and biologist, primarily to supply the export markets which had formerly drawn on German manufacturers for their needs of biological stains. Another object of the founder was to gain freedom and facilities for research and writing in his own style on the topics closest to him, namely the chemistry and use of biological stains and the simplification and rationalization of histological staining. $\mathrm{He}$ has published several books and has contributed a number of research papers to various journals, all with this object in view.

\section{Introductory Courses in Genetics}

THE fourth edition of Dr. Charlotte Auerbach's Notes for Introductory Courses in Genetics (Pp. 42. London: Oliver and Boyd, Ltd., 1965. 3s. 6d.) again emphasizes that the booklet is not intended to compete with any textbook, however elementary. Even less is it meant to be a popular introduction to genetics, although it may prove useful to scientists in other fields who require a concise exposition of the basic concepts and laws of genetics. The object of the book is to help students who attend courses in elementary genetics, especially the short courses given to medical students and first-year agricultural students, and for their special requirements two appendixes have been added. The Notes should relieve the students of the necessity of taking their own notes on a subject which requires great accuracy and clarity of terminology. The book has, in fact, grown out of dictations to students, and has successfully replaced these dictations in Dr. Auerbach's own introductory courses.

\section{Translation and Interpretation}

THE chief features in The Incorporated Linguist, tho journal of the Institute of Linguists for April 1965, are Mr. S. Soubbotnik's article on "Interprotation in the United Nations and its Specialized Agencies"; Mr. R. Hartman's comparative review of the bilingual dictionaries of English and German; and Dr. van Abeés discussion of overcoming initial difficulties in teaching a modern language.

\section{Psychological Investigation of Card Punching}

BEHIND each brief summary of multifarious fact provided by data-processing lie not only the achievements of electronic engineering but hours of humdrum card punching by young women, some of whose supervisors report that for this work the level of intellectual attainment represented by General Certificate of Education (Ordinary Level) passes is a positive drawback. Yet their work demands manipulative speed and accuracy, with considerable montal alertness in ordering and coding the raw data, and they need 3-6 months training. The National Institute of Industrial Psychology has made a preliminary survey of the problems of selection, training and methods of work that this entails (National Institute of Industrial Psychology. Report No. 18: Card Punching: a Study of the Work and the Factors that Affect It. By Leonora Johnston. Pp. 40. London: National Institute of Industrial Psychology, 1965. 8s. 6d.). That problems really exist is indicated by the high leaving-rate among operators, and the standard view that it results mainly from marriage and pregnancy is shown to be untenable. Any programme of selection and training in this field has to face unexpected difficulty in assessing performance, largely because of wide variations in the nature and layout of the information to be punched. The Institute's investigator met the familiar industrial situation of rather elaborate record keeping which everyone concerned knows to be misleading, and although she tactfully accepts the view that it serves well enough for practical purposes it will obviously not meet scientific needs. The report, however, begins to bring the problem within range of systematic investigation, and it is to be hoped that further work can be undertaken in an area where widely differing practices prevail, each at present supported with more conviction than evidence.

\section{North Staffordshire Field Club}

ThE North Staffordshire Field Club celebrated its centenary on April 18. Founded for the purpose of studying the natural history of the district, its scope was soon extended to include local history and archaeology, and early members contributed notably to the knowledge of the North Staffordshire Coalfield. In recent years a close liaison has developed between the Club and the University of Keele; in 1960 the Transactions of the North Staffordshire Field Club were incorporated in the North Staffordshire Journal of Field Studies, which is edited in the University. The president of the Club for the centenary year is Mr. H. V. Thompson, formerly head of the Depart. ment of Chemistry in the North Staffordshire College of Tochnology.

\section{Fossil Tapirs}

Is contrast to the voluminous writings on other fossil perissodactyls, tapiroids have been long neglected. Prof. Radinsky's recent monograph, entitled Early Tertiary Tapiroidea of Asia, does much to redeem this - a work all the more remarkable when one realizes that the material which is described has lain in the American Museum for more than forty years (Bulletin of the American Museum of Natural History. 129, Article 2. By Leonard B. Radinsky. Pp. 181-264 + plates 1-4. New York: American Museum of Natural History, 1965. 3 dollars). Radinsky's earlier works have clarified the location of Mongolian Tertiary sites and their stratigraphy. This work sheds new light on the earliest ceratomorphs, a taxum which bristles with taxonomic difficulties. Radinsky describes three new tapiroid genera and rearranges the classification of early tapirs in the light of all known matorial, mostly Russian and Chinese. His re-grouping of genera within families still leaves an uncomfortably large number of incertae sedis specimens. In spite of this, his descriptions of dentitions and limb bones, adequately illustrated, mako a welcome contribution. Prof. Radinsky comments on the interesting contrast between the diverse tapiroid fauna of the Asiatic Eocene with the relative paucity of artiodactyls, and the reverse position in contemporary North America and Europe where artiodactyls predominated; he suggests the influence of ecological factors. The 'grande coupure' still remains between early and late Tertiary tapiroids, as it does for numerous other mammalian taxa. 